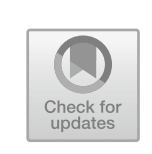

\title{
The Moral Ecology of Good Wealth
}

\author{
Michael Naughton
}

What is good wealth? What are its sources? What logic helps us toward its created potential? What practices define and sustain its goodness? And, to the contrary, how does wealth go bad? What are its disorders? And what logic seduces us to create bad wealth?

To get at these important questions, we need to avoid the all too often prideful and relativistic response that gives a morally and spiritual deprived answer: "I get to decide what is good." "It is my decision." "I earned it, and so I control my wealth." People of wealth who think they are the source of their wealth suffer from deadly capital vices and in particular from acedia (Greek akedia, a (absence) + kedos (care), not caring about caring, indifference) a spiritual laziness that fails to get to the root of reality.

A fruitful approach to a vision of "good wealth" is to see the interdependent and organic relationship among wealth's creation, distribution and charitable dimensions. The relationship among these three stages of wealth fits well with what Catholic social teaching refer to as "moral ecology," where we see and act on the profound interconnected dimensions of what good wealth is in terms of a good life and a good institution.

\footnotetext{
M. Naughton $(\varangle)$

University of St. Thomas, St Paul, MN, USA

e-mail: mjnaughton@stthomas.edu

(C) The Author(s) 2020

T. Akram and S. Rashid (eds.), Faith, Finance, and Economy, https://doi.org/10.1007/978-3-030-38784-6_10
} 
Within this moral ecology, we can also begin to see our blind spots not in a judgmental moralistic way, but in a way of humility of receiving the deeper truths of our humanity.

Where I want to begin in this approach is with institutions and in particular with business as an institution. Some of the biggest debates we face as a country is over how we understand the purpose of the institutions we live in and in particular the goods such institutions should strive for. This is no small matter. One of the most significant responsibilities of leaders in any organization is to articulate, cultivate and execute the purpose of the institution they lead. What the purpose question does for an institution is that it clarifies what goods are to be pursued by an institution and how it orders such goods for the good of the whole. This has massive implications for the quality of the society we live in. It is precisely such purposes that give institutions meaning as well as legitimacy in the communities where they reside.

The pursuit and articulation of institutional purpose is not as easy or as direct as it may seem, however. One challenge is the significant cultural debate over the institutional purposes of business and the goods it should promote, universities and education in general, family and the meaning of marriage, religion and whether it is good for society, government and health care. Because of the increasing pluralism of society, we have difficulty agreeing to a common understanding of the good-the common good, so our tendency is to go to the least debatable "thin" approach to the good. This move toward a "least common denominator," unfortunately, "flattens" or "dilutes" the good of institutions by reducing them from a vibrant set of integrated goods to one emotive or instrumental good-business to shareholder wealth maximization; universities to career credentialing; religion to emotive experience; marriage to sentiment between autonomous individuals; and so forth.

In this paper, I want to focus on the institution of business as a way at getting at what we mean by "good wealth." In one sense, much of the economic wealth generated in this country comes from business and consequently its distribution and charity, and if we are to examine what is "good wealth" we need to engage business. But first we need to ask the larger question: what is the good business does? ? $^{1}$ The document Vocation of the Business Leader produced by the Vatican's Pontifical Council for

${ }^{1}$ See Robert Kennedy, The Good That Business Does (Acton Institute, 2006). 
Justice and Peace (now called the Dicastery for the Promotion of Integral Human Development) speaks about three goods business contributes to the common good of society ${ }^{2}$ :

- Good Goods: Making goods that are truly good and services that truly serve;

- Good Work: Organizing work in which employees develop their gifts and talents so as to serve the larger community; and

- Good Wealth: Creating sustainable wealth so that it can be distributed justly to the institution's contributors.

Business is a goods producing institution. When all three goods are present, business contributes positively to the social conditions that make it "easier" to foster integral human development-the flourishing of persons and communities. This is what the Catholic social tradition defines as the common good.

In this paper, I focus on the meaning of "good wealth" keeping in mind the interrelated dimensions of the other two goods of businessgood goods and good work. I want to focus on what I will call the three interdependent dimensions of good wealth: (1) stewardship-wealth creation, (2) justice - wealth distribution and (3) charity-wealth dispersion. To understand the relationship of these three dimensions and their importance, a quick glance at one of the great business leaders in United States history, Andrew Carnegie, can be helpful in orienting us to the issues we need to face.

In terms of wealth creation, Carnegie was one of the great entrepreneurial immigrants the US has seen. He went from doing modest low-level organizational tasks to becoming one of the great American industrialists of the nineteenth and early twentieth century. As an immigrant who was a "capable, energetic, ambitious, discontented man," he built the Carnegie Steel Corporation into the largest steel manufacturing company in the world. Influenced by the social Darwinist Herbert

${ }^{2}$ Vocation of the Business Leader (Vatican City: Pontifical Council for Justice and Peace, 2014). https://www.stthomas.edu/media/catholicstudies/center/ryan/publications/ publicationpdfs/vocationofthebusinessleaderpdf/PontificalCouncil_4.pdf. I find the language of "goods" to be an important language of business. As Lewis explains "Goods are ends just in so far as they serve to perfect." See V. Bradley Lewis, "Is the Common Good and Ensemble of Conditions," Archivio di Filosofia, LXXXIV, 1-2 (2016), 130. 
Spencer and other thinkers such as William Graham Sumner (although how Carnegie' Presbyterian upbringing connects and does not connect to the Darwinian influence is beyond this paper) as well as by the highly competitive businesses he worked in, Carnegie viewed business in terms of the logic of the market. The logic of the market presupposes that nothing is given, that things are only acquired and we wrestle out of nature her fruits.

In terms of distribution, Carnegie was given the name "robber baron" along with other American industrialists, such as Rockefeller, Vanderbilt and Gould. Influence by the Darwinian principle of the survival of the fittest, Carnegie unethically crushed competitors, bribed government officials and broke unions. A defender of laissez-faire economics, he drove costs down including labor costs. This led to sub-living wages and poor conditions, hostility to unions, resistance to government regulation except when it protected his firm, and a fundamental allergic reaction to justice and equity. He actually believed that the concentration of capital was necessary for societal progress by those who knew how to create wealth. For Carnegie, unions for example, impeded the evolutionary progress of the market by "unnaturally" pushing up the cost of business and protecting the narrow interests of labor.

In terms of charity, Carnegie famously wrote he "who dies rich, dies disgraced." He saw himself as well as others with resources as trustees of their wealth who should live without extravagance, provide moderately for their families, and use their riches to promote the welfare and happiness of others.

There is much to admire about Andrew Carnegie as well as many other entrepreneurs and business people who work hard and give much. His virtues of personal frugality, sacrifice and hard work are essential for good business. But like all of us, they have significant blind spots. For Carnegie, he saw little inconsistency between how he distributed his wealth and how he created it as well as gave it away. The point here is not to condemn Carnegie. There is way too much condemning of historical figures from the modern perch. But good qualities become polluted when businesspeople discount one of the important functions of good wealth such as its distributive function. And it should be noted that there are many blind spots in discerning good wealth, such as those social justice warriors who denigrate charity and who only see justice in terms of the regulations of the state. Or companies that create harmful products such as pornography 
or tobacco, yet, justify their firms because they pay just wages and taxes. Good wealth entails a moral ecology where all three functions are interconnected. When one function is in disorder, the whole is disordered. This paper explores in detail the three functions of good wealth and their ordered interconnections.

\section{Wealth Creation: Stewardship}

In terms of wealth creation, business enterprises are the economic engine of society. As a creator of products and services (good goods) and jobs (good work), business must exercise the stewardship of resources in a way that it creates more than what it has been given. ${ }^{3}$ Good stewards of wealth are those who do not only take from creation's abundance, but they contribute to it. In business, this stewardship demands a great deal of frugality and economic discipline, tracking carefully costs and revenue, driving out waste, improving production processes, delivering on time, enhancing quality, and so forth.

When a business generates more than what has been given to it, we call it profit or margin, a surplus of retained earnings over expenses. This profit enables a company to sustain itself into the future. Profits wisely used over time create equity in companies, which strengthens the firm's wealth generating capacities to build for the future. A business with a healthy balance sheet, for example, simply has greater abilities to build a future than those laden with debt. It can handle the unexpected downturns of the economy. A profitable business creates the conditions for well-paying jobs, opportunities for employee development, useful products and services, satisfied customers, and vibrant communities.

Yet, profit is like food. You need it to be healthy and sustainable, but you ought not to live for it. It is a means not an end, a reward not a motive (which is why so many executive incentive programs can be so destructive). Profit makes a good servant, but a lousy master.

When profit becomes the master, however, businesses often ignore or discount what have been given. The two most significant gifts they receive and co-create with are nature and family. If they fail to recognize these gifts, crisis usually follows. Take for example nature. The most basic gift we inherit is nature. Without the goods of creation, we are bankrupt.

${ }^{3}$ Matthew 25:14-30. 
We have become increasingly aware, although not as fast as we should, of the demands of the proper stewardship and use of the environment. The book of Genesis tells us, to "till and keep" creation, but we have tended to "till too much and keep too little." 4 The importance of recycling, reducing carbon and driving out waste, recognizes our dependence upon nature. Of course, nature does not give its wealth without human work and its distinctive human qualities of creativity and ingenuity. Yet, while the wealth of our economy is increasingly coming from the knowledge of workers, businesses will always be beholden to the gift of nature and of the land.

The other great gift that business receives that enables it to function is the family. When we praise leaders for their work ethic, we are often indirectly praising their parents. We stand on the shoulders of our families who have done far more than we know to get us to where we work and live. If a business is morally sound it is often because the families of those who inhabit the business are morally sound. What marriage and family do for people is they provide the social conditions for people to develop. Family is a primary institution that fosters the common good. They provide what the sociologist Robert Putnam calls "social capital." They create enduring relationships that mutually support its members especially during difficult and trying times. They bond people together. They create the capacity for people to make sacrifices. And despite all their challenges, they create the stability that supports political and educational institutions all of which feeds into the possibility of an economic system. Yet, as several scholars have noted, family structure is too often ignored or discounted when speaking about the economic health of society and in particular business. 5

There are other gifts that businesspeople receive that contribute to their ability to create wealth such as good laws and government. Would a Steve Jobs have been able to flourish in North Korea, probably not. Government plays an important role in establishing just taxes,

\footnotetext{
${ }^{4}$ Cardinal Peter Turkson, "Protect the Earth, Dignify Humanity: The Moral Dimensions of Climate Change and Sustainable Development", delivered at Vatican City, April 28, 2015, http://www.casinapioiv.va/content/dam/accademia/pdf/turkson.pdf. Accessed August 21, 2018.

${ }^{5}$ See the work of Charles Murray, Coming Apart: The State of White America, 19602010 (New York, NY: Crown Forum, 2012).
} 
reasonable regulation and healthy incentives to foster wealth creation. For example, many of the new jobs, which are critical to a healthy business sector, usually come, not from well-established companies, but from entrepreneurial start-ups, small and medium-sized companies, especially family businesses. ${ }^{6} \mathrm{New}$ businesses need entrepreneurs who are willing to take risks, who have faith in the future, who have access to credit and who can operate in a reasonable regulatory environment. Good government will make all these opportunities to create wealth easier and more likely.

\section{Wealth Distribution: Justice AND Right RELATIONSHips}

Wealth creation, however, is only one side of the proverbial wealth coin. We also need to speak of wealth distribution, and in particular a just distribution. So, without profit a company dies, but without justice and a just distribution of wealth a business is organized robbery. ${ }^{7}$ This is seen in price gouging and fixing, monopolies, hoarding benefits and incentives to executive leadership, shifting costs onto the poor and future generations, refusal to pay suppliers or unreasonable extension of payments, corporate welfare and wage theft, and the list goes on.

Precisely because of the abuse of business in relation to its duty to justly distribute wealth, too often, however, a just distribution of resources is seen as only a political function. While the state plays an important role through regulations and taxation in distributing wealth, the role of business as a distributor of justice cannot be ignored. What business, like any institution, must address is how it establishes "right relationships," which

\footnotetext{
${ }^{6}$ http://sbecouncil.org/about-us/facts-and-data/. Accessed August 21, 2018.

${ }^{7}$ One of the serious moral debates we are having in our society is whether there is a "just distribution" of resources. A recent Pew Study rank of concerns for Americans placed "income inequality" as the number one concern on the list they had (higher \% of democrats; lower $\%$ of republicans). This debate is a perennial one. There are few people in this world who would argue for an equal distribution of income, recognizing that an unequal distribution of wealth can be morally legitimate. There are also few people who would justify the current patterns of wealth distribution as morally sound and legitimate. An important question for us is when does inequality of income and wealth become immoral and unjust? One dimension of the debate is where does one focus: wealth creation or wealth distribution.
} 
is at the heart of justice. The Latin root of justice is ius, which means "right," and in particular "right relationships." In Hebrew mišpāt (justice) and şĕd $\bar{a} q \hat{a}$ (righteous) in the Old Testament describe the fulfillment of responsibilities between employer and employee and ruler and people, as well as God and his people, husband and wife and parent and child.

The key to this right relationship in business is the way wealth is distributed. Pius XII made the analogy of wealth being like blood in the human body, it needs to circulate to all the parts in order to make the whole healthy. ${ }^{8}$ Good wealth depends upon not only its creation but also a just distribution; where there is a concentration of wealth, there is most likely clotting causing disease. Business plays an essential role in creating a just distribution of wealth that both generates authentic prosperity and alleviates debilitating poverty. When excessive inequality, greater distance between rich and poor, exceed certain thresholds, regions and countries become ripe for increasing distrust, alienation, violence, crime and possible revolution. Business plays an essential role in creating a just distribution of wealth that both generates authentic prosperity, fosters right relationships and mitigates economic inequities.

As it relates to business, a just distribution calls for wealth to be allocated in a way that creates "right relationships" with those who have participated in the creation of such wealth. This virtue raises a set of knotty and enduring moral challenges for business leaders. Among other things, businesses need to discern and account for the moral implications of how they allocate resources to employees (a just wage and compensation as well as possibilities of employee ownership), customers (just prices), owners (fair returns), suppliers (just prices and fair terms on receivables), government (just tax payments) and the larger community and especially the poor (philanthropy). ${ }^{9}$

${ }^{8}$ Pius XII, Letter Dilecti filii to the German Bishops, October 18, 1949; quoted in Jean-Yves Calvez and Jacques Perrin, The Church and Social Justice: The Social Teachings of the Popes from Leo XIII to Pius XII (Chicago: Henry Regnery, 1961), 149.

${ }^{9}$ These issues raise the moral debate today about rising inequality. While there are many dimensions to this issue, in the United States one particular element is the allocation of historically high profit margins to capital and away from labor. Shareholders and those representing shareholders and in particular senior management saw their incomes rise faster than labor since the 1990s; whereas labor rates have stalled. The reasons for this are complex and varied: globalization, technology, financialization of the economy, decline of unions, deregulation as well regulation of corporate benefits (Washington/Wall 
One of the most significant, although certainly not the only, ways businesses address wealth distribution is whether they pay a "just wage." The just wage is a complex topic, but its importance in a just distribution cannot be underestimated. When an employer receives work from an employee, both participate not only in an economic exchange, but also in a relationship that is both institutional and personal. This relationship, if it is to be just, has three convictions that should guide the distribution of wealth: need, contribution and order.

- Need: For a relationship to flourish in business, an employer must recognize that employees, by their labor, "surrender" their time and energy and cannot use them for another purpose. A living wage, then, is the minimum amount due to every independent wage earner by the mere fact that he or she is a human being with a life to maintain and a family to support. A wage that fails to meet the needs of an employee (in particular a full-time adult) is a wage that will struggle to carry the weight of a real relationship.

- Contribution: While the principle of need is necessary for determining a just wage, on its own it is insufficient, since it only accounts for the consumptive needs of employees and does not factor in their productive contributions to the organization. Because of effort and sacrifice as well as skill, education, experience, scarcity of talent and decision-making ability, some employees contribute more to the organization than others, and are due to more pay. An equitable wage, then, is the contribution of an employee's productivity and effort within the context of the existing amount of profits and resources of the organization.

Street collaborations), etc. The temptation here, however, is to reduce wealth distribution to merely impersonal forces that need to be technically managed either by greater deregulation of the market so as to expand the pie or by greater government regulation to more justly distribute the pie. While market or government solutions are important, businesses and their leaders need to bring to the table a more robust set of principles in how wealth is distributed within the organization in a way that is sustainable in a market economy. One such solution is to find ways to broaden the ownership of capital so that more people participate in its benefits-cooperatives and employee stock ownership plans (ESOPs) are two such forms. Building up ways in which the poor can have wealth increases their chances of moving and staying out of poverty more than only having them depend upon income generation (see James P. Bailey, Rethinking Poverty, Income, Assets and the Catholic Social Justice Tradition [Notre Dame, IN: University of Notre Dame Press, 2010]). 
- Order: Pay is not only income for the worker, but it is also a cost to the employer, a cost that impacts significantly the economic order of the organization. Without proper evaluation of the way a living and equitable wage will affect the economic order of an organization, the notion of a just wage becomes no more than a high-sounding moralistic impracticality. A sustainable wage, then, is the organization's ability to pay wages that are sustainable for the economic bealth of the organization as a whole.

What makes a just wage complex and difficult is that these three convictions are often in tension with others. For example, a tension can exist between the principle of need and the principle of order. Raising wages to a livable level especially for those jobs that are unskilled can put the economic sustainability of a business at risk. The key to resolving the tension is by invoking the principle of contribution. Three conditions of relationship are necessary to come to a fruitful resolution. What business leaders resist is the all too common attitude of passively delegating their responsibilities simply to the mechanical force of labor markets. As managers they are moral agents, distributors of justice, not mere market technicians.

Yet, we need to be clear here that businesses are not responsible to pay employees more than a sustainable wage (a wage consistent with the sound financial management of the firm), even if that wage falls below a living wage. To do so would unjustly place businesses-and all the firm's employees - at risk of economic failure. In a market economy, no organization can be obligated to pay without regard to labor costs' effect on its competitive position, since that would amount to an imprudent choice, leading possibly to economic failure for the business. To "impose justice" in this manner is doomed to long-term failure.

\section{Wealth Dispersion: Charity and the Logic of Gift}

The charitable function of wealth is in many respects the most excellent of the three functions of wealth, since it is in the charitable function that we get at the underlying logic of gift that defines for us what "good wealth" is. It is also the logic of gift that has power to order the logics of the market (incentives) and the contract (rules and procedures) and prevent their disordering practices.

Unfortunately, charity has received such a bad name, in part because of people like Carnegie and others whose charitable giving off the backs 
of labor taints the charity. The lawyer, for example, who does mergers and acquisitions during the day that leads to layoffs and then does pro bono work in the evening for women who have been beaten by their laid-off husbands should at least create an unease of the justice of work and charity of volunteering.

This tension and even contradiction between justice and charity has created a long line of critics of charity who are concerned that charity is used as a substitute for justice. They characterize charity as paternalistic by combining pity with power creating relationships of the giver as superior and the receiver as inferior. Such criticisms are real and have legitimate validity. Unfortunately, they often dismiss charity and fail to recognize its power. In doing so they sever themselves from the power of charity, and when they do, their justice grows cold. What is needed here is a robust notion of charity that complements and fulfills justice.

The problem with charity is not that there is too much of it but too little. "There is little justice in the world because there is little charity in the world and there is little charity in the world because there is little God in the world." 10 Charity goes beyond justice, but it never lacks justice. The two are inseparable from each other and when they are disconnected both are damaged. Pope Benedict put it this way:

On the one hand, charity demands justice: recognition and respect for the legitimate rights of individuals and peoples. It strives to build the earthly city according to law and justice. On the other hand, charity transcends justice and completes it in the logic of giving and forgiving. The eartbly city is promoted not merely by relationships of rights and duties, but to an even greater and more fundamental extent by relationships of gratuitousness, mercy and communion. Charity always manifests God's love in human relationships as well, it gives theological and salvific value to all commitment for justice in the world.

What charity should always help us to understand is, that we have first been gifted so much in life and that our giving needs to reflect the gift that has been received. As Jesus states "From everyone who has been given much, much will be demanded; and from the one who has been entrusted with much, much more will be asked" (Lk 12:48). Ultimately,

${ }^{10}$ From the Introduction by Peter J. Howard in Fulton Sheen, Justice and Charity (TAN Books, 2016), 3. 
one of the principal failures of mainstream business theory and practice is to see capital as a form of property that has a social and spiritual nature, and labor as a form of work that has moral and spiritual meaning. Without this idea of gift and where it comes form and who gives the gift, business will always be prone to utility maximization based on individual interests.

Josef Pieper argued that the key to the moral and spiritual crisis of modern society is the refusal to accept such a gift. He explained that there is "the strange propensity toward hardship that is engraved into the face of our contemporaries as a distinct expectation of suffering." $11 \mathrm{He}$ asks whether this propensity toward work, toward career, toward achievement, toward technology is perhaps the deepest reason for the "refusal to accept a gift, no matter where it comes from?" 12 Have we lost the ability to receive gifts? Are we unable to think with a logic of gift? Have we deluded ourselves into thinking that everything is acquired, earned and achieved? ${ }^{\text {13 }}$

Benedict as well as Pieper are getting at this modern problem by helping us to see how this dynamic between receiving and giving must be informed by charity. Benedict defines charity as "love received and given." 14 The phrase is the beginning of what we mean by a "logic of gift." This logic of receiving and giving is like the inhaling and exhaling of life. It begins to describe the dynamic relationship between the contemplative and active life within the person, which informs the nature of relationships that are first and foremost expressed in family and faith communities, but also informs work communities. Before addressing the issues in relation to current business thinking, I want to highlight three particular claims that this dynamic and complex operation of receiving and giving brings with it, and how these claims inform how we understand the business through a logic of gift.

${ }^{11}$ Josef Pieper, An Anthology, 138. See Leisure the Basis of Culture (South Bend, IN: St. Augustine's Press, 1998), 19.

12 Josef Pieper, An Anthology, 139. See also Jacques Godbout's discussion of the premises of Alcoholics Anonymous, namely, that the alcoholic "cannot solve his or her problem alone, and must recognize that the capacity to find a solution comes from outside, from a gift bestowed by a superior force" (The World of the Gift [Montreal: McGill-Queen's University Press, 1998], 69).

${ }^{13}$ See Pieper Leisure the Basis of Culture, chapter II. Pieper sees this inability to receive as both an ethical and epistemological problem. He explains that Kant's notion of knowledge work plays a destructive role in this significant problem of not receiving.

${ }^{14}$ Caritas in veritate, 5 . 
The first claim is that love as a dynamism of receiving and giving strikes at the heart of how we develop as persons. In the first sentence of his encyclical, Caritas in Veritate, Benedict explains that this charity "is the principal driving force behind the authentic development of every person and of all humanity." 15 These two fundamental dimensions of our lives, of receiving and giving, of contemplation and action, of rest and work are not simply two isolated periods of time in human life, but rather they are, as Karl Rahner S.J. explains, "moments in a person's self-realization which exist only in their relation with one another and are the primary constituents of human existence itself." 16 The point here is that love is not only an act of giving but also receiving and this act of receptivity, of rest, contemplation, prayer, worship plays an essential role in the integral development of the person. This will be explained in more detail in the next two sections.

The second claim, which is of critical importance to highlight in our current situation is that the receiving dimension of this charity has a certain primacy. The structure of this love "expresses the primacy of acceptance over action, over one's achievement." 17 David Schindler expresses this well: "When we first experience our being as created, as being gifted life, this receiving enables us to see our doing and having ... as ways of giving which they are meant to be." 18 This is why Benedict, as Cardinal Ratzinger, states that the person "comes in the profoundest sense to himself not through what he does but through what he accepts," not through what he achieves but what he receives. ${ }^{19}$

The third claim, which builds upon the prior two claims, is that if this deep receptivity fails to animate organizational life, that place where we give of ourselves, we will find ourselves in a disordered relationship in every exchange. This is why Benedict explains that " $[t]$ he great challenge before us ... is to demonstrate, in thinking and behavior ... that in commercial relationships the principle of gratuitousness and the logic of gift

15 Caritas in veritate, 1.

${ }^{16}$ Karl Rahner, "Theological Remarks on the Problem of Leisure," Theological Investigations, vol. IV. trans. Kevin Smyth (Baltimore: Helicon Press, 1966), 379.

${ }^{17}$ Joseph Ratzinger, Introduction to Christianity, trans. J.R. Foster (San Francisco: Ignatius Press, 1990), 266.

${ }^{18}$ David Schindler, "Christology and the Imago Dei: Interpreting Gaudium et spes," Communio 23 (Spring 1996): 159.

${ }^{19}$ Joseph Ratzinger, Introduction to Christianity, 266. See also Caritas in veritate, 52. 
as an expression of fraternity can and must find their place within normal economic activity." 20 It is actually this logic of gift that illuminates the blind spots of businesses creation and distribution.

Charity "makes room" and provides space for a "logic of gift" that orients people in business to deeper levels of communion, solidarity and fraternity. ${ }^{21}$ When charity and its logic of gift is muted or discounted certain distortions begin to seep into the creative and distributive functions of Wealth. In terms of the creative function, the businessperson is tempted to see only their achievement of wealth creation in terms of their own effort. The term wealth creation, however, is a bit of a misnomer since we as humans never really create anything, but what we do is transform what has already been given. Only God creates ex niliho, "out of nothing." Everything that we have is gift. We simply utilize in creative and innovative ways what has already been given. In our creativity, we reflect the image of the creator God we have been made in.

One interesting practice that embodies this charity in business is corporate giving. This activity has a particularly long tradition in the state of Minnesota. Many know that the Target Corporation donates approximately $5 \%$ of its pretax operating profit and is consistently ranked as one of the most philanthropic companies in the US. What some may not know is where this tradition comes from, which moves us to the virtue of charity.

Target's original impulse for this practice started with its founders in the nineteenth century, and in particular George Draper Dayton who wrote "there's a divinity that shapes our lives" and for whom tithing part of his profits for the poor was a biblical command and not a corporate strategy for public relations to generate greater profit. ${ }^{22}$ Influenced by the biblical vision of the world and his Presbyterian upbringing, the fruits

\section{${ }^{20}$ Caritas in veritate, 36.}

${ }^{21}$ Caritas in veritate, 34, 37. "Space also needs to be created within the market for economic activity carried out by subjects who freely choose to act according to principles other than those of pure profit, without sacrificing the production of economic value in the process. The many economic entities that draw their origin from religious and lay initiatives demonstrate that this is concretely possible" (37). See for example the companies associated with the Economy of Communion, family businesses, cooperatives, entrepreneurial ventures, and other types of firms inspired by faith, etc. These communities of persons are not without their contracts and economic rationality, but these realities do not exhaust the meaning of such communities.

${ }^{22}$ Wilfred Bockelman, Culture of Corporate Citizenship: Minnesota's Business Legacy for the Global Future (Lakeville: Galde Press, 2000), 34. 
of his work were not his own but God's and the implication was that part of those fruits went to the poor. Dayton's self-understanding was grounded in a profound notion of wealth that had spiritual and moral claims to it.

The founders of Reell Precision Manufacturing had a similar conviction and they also tithe their profits at $10 \%$ of pretax earnings. Several years ago Reell established a yearly service trip to the Dominican Republic (DR) working with a local church and a local Dominican couple to establish a campus with a school dining hall, playground and chapel. Every February for the past six years, approximately 15-20 coworkers spend a week in the DR. There is much to say about the program, but I want to highlight the logic that drives it and the collateral goodness that comes from it that impacts in a powerful way the creative and distributive functions within Reell. ${ }^{23}$

First, for Reell, the $10 \%$ of pretax profits are not spent because the leadership team thinks such spending will generate ever greater profitability or greater retention or some other instrumental benefit. It is done out of principle of the tithe, which states that the first fruits are given to those who go without. While some companies may give to charities out of a purely instrumental rationale, such instrumental thinking will often eventually do damage to the actions. Such calculated rationality pollutes the act even though the act will have great benefits. T. S. Eliot once put it "The greatest treason is to do the right deed for the wrong reason." While few of us ever have completely pure intentions, our motives matter, especially over time, and they either move to a more narrowly self-focused quid pro quo exchange or they move to a more generous openness to the other.

Second, serving the poor together in the DR has served as a school of servant leadership. When board members, the CEO, mid-level managers and assembly line persons are working side by side digging ditches, visiting homes of local Dominicans, hearing about their situations and then reflecting upon their experiences, they immerse themselves in a situation that increases the chances to touch the heart. Servant leadership as an abstract principle is often difficult to understand in words. It needs to be experienced in order to be understood.

${ }^{23}$ See Michael Naughton and David Specht, Leading Wisely in Difficult Times: Three Cases on Faith and Work (co-author David Specht), Paulist Press, Fall 2011. For full disclosure, I am the chairman of the board of directors for Reell. 
Third, there is always a collateral goodness to tithing, although the exact nature of that goodness can be unexpected. As John Henry Newman put it, "the good is always useful but the useful is not always good." The collateral goodness of the trip has had a positive impact on the culture of the organization in multiple ways. In particular it has brought unity to longer tenured members of the company with newer coworkers. With new leadership in the company, there were longer tenured coworkers who felt that leadership did not "get" the mission of the company. The trip brought both new and old together, which began to bridge the gap. It has brought stronger relationships with those coworkers who work in the different facilities in the Netherlands, China and the USA. It has also had a significant impact on those Dutch coworkers who tend to see charitable works more the responsibility of the government rather than the corporation. All of these connections have strengthened the relationships among coworkers that has created teambuilding, retention of coworkers and attracts new workers.

Fourth, the spiritual gifts received and connections made are beyond measure. After seven years of trips, there is a community of Dominicans who not only pray and fast for the project, but they pray for the individual coworkers and for the company as a whole. This relationship between Dominicans and Americans has brought a spiritual dimension that is captured by Benedict's notion of fraternity:

As society becomes ever more globalized, it makes us neighbors but does not make us brothers. Reason, by itself, is capable of grasping the equality between men and of giving stability to their civic coexistence, but it cannot establish fraternity. This originates in a transcendent vocation from God the Father, who loved us first, teaching us through the Son what fraternal charity is. ${ }^{24}$

Such spiritual and relational intimacy the moves people into a familial relationship of brothers and sisters in business-related community outreach projects will make most executives uneasy. And it should. Intimate relationships can easily disorder and unrealistic expectations can come from either side. Reell, for example, has been very clear with the Dominicans that there are limits of what they can do and that the ultimate end of

${ }^{24}$ Caritas in Veritate, 19. 
the project is to get to a place where Dominicans are self-supporting. But the spiritual relationship has been one of the surprises of the project. It natural emerged rather than orchestrated.

Finally, a brief note on the relationship and tensions among the charitable, creative and distributive functions of good wealth. First, in relation to creation. If the company does not create wealth, it cannot give it away. Since implementing the DR project, the company's profit have been extremely healthy. This does not mean that economic challenges will not return to the company, but as profound as the charity giving has been, it is dependent upon profit. To be a profitable and well-run company you have to have the right people in the organization. In the span of these seven years, the CEO and the Vice President of Coworker Services (human resources) has had to let several people go for various reasons including some key leadership positions who have actually been on the DR trip. It is not easy to fire someone who you have worked arm in arm on such a charitable cause. But if coworkers are not contributing to the overall good of the company, leadership must first attempt to help toward that goal and if it does not work, they must let them go.

Second, not all coworkers of the company have been committed to the project and some have even expressed that the company tithe should be eliminated and redistributed to them. While this is less of a problem today than it was seven years ago, coworkers can be just as self-interested as shareholders and executives. Self-interest ordered toward one's own wealth maximization damages culture. It highlighted the importance for executives that charity was not fully incorporated in the culture of the company. In those seven years, however, the DR project has been one of the most important activities of contributing to what it means to be charitable not only to the poor but to each other. Coworkers and those board members who go to the DR first experience a deep sense of what has been given to them. They are thinking not that they should have more, but they experience a deep sense of gratitude. In that gratitude, then, is a welling up of a desire to give. Charity is a love of receiving and giving and it becomes a habit not only with those in the DR, but in the business back in Minnesota. Charity purifies wealth and makes it good by reminding us of where it ultimately comes from. 


\section{CONCLUSION}

One of the principal challenges of modernity is a divided life that fragments a moral ecology that frustrates moral and spiritual meaning, deeper relationships and a unity of life. With regard to wealth, we are prone to fragment its creative, distributive and charitable functions into discrete separate units. If we are to generate good wealth, we need to create as good stewards, distribute as agents of justice and give it away as charitable lovers. But these are not three distinct and separate virtues but they mutually inform each other in a way that generates what this paper has called a moral ecology. This moral ecology is premised on virtues that are related to another and if one is missing the other begins to become disordered. This is what people like Aquinas and others call the "unity of the virtues." So what makes "good wealth" good is precisely the virtues of a moral ecology that fosters an interdependent and organic relationship among its creative, distributive and charitable dimensions. One dimension is related to other which is why it is not helpful to juxtapose wealth creation and wealth distribution or charity and justice. Once we are in this frame of mind we are outside of a moral ecology and have fallen tramp to what Alasdair MacIntyre has called compartmentalization, where contemporary social life is separate "into distinct spheres, each with its own highly specific standards of success and failure, each presenting to those initiated into its particular activities its own highly specific normative expectations, each requiring the inculcation of habits designed to make one effective in satisfying those particular expectations and conforming to those particular standards." 25 The principal challenge is not dividing these three areas of creation, distribution and charitable but providing a social vision of how they are related. As expressed in this paper, this is not an easy work and it behooves us to open ourselves to deeper connections among the three functions of wealth. Within this moral ecology, we can begin to see our blind spots not in a judgmental moralistic way, but in a way of humility of receiving the deeper truths of our humanity and our world.

${ }^{25}$ Alasdair MacIntyre, "Moral Philosophy and Contemporary Social Practice: What Holds Them Apart?" The Tasks of Philosophy. Selected Essays, vol. 1 (Cambridge: Cambridge University Press, 2006), 117. 


\section{BIBLIOGRAPHY}

Bailey, James P. Rethinking Poverty, Income, Assets and the Catholic Social Justice Tradition. Notre Dame, IN: University of Notre Dame Press, 2010.

Bockelman, Wilfred. Culture of Corporate Citizenship: Minnesota's Business Legacy for the Global Future, 34. Lakeville: Galde Press, 2000.

Calvez, Jean-Yves and Jacques Perrin. The Church and Social Justice: The Social Teachings of the Popes from Leo XIII to Pius XII, 149. Chicago: Henry Regnery, 1961.

Godbout, Jacques. The World of the Gift, 69. Montreal: McGill-Queen's University Press, 1998.

Kennedy, Robert. The Good That Business Does. Grand Rapids: Acton Institute, 2006.

Lewis, V. Bradley. "Is the Common Good and Ensemble of Conditions." Archivio di Filosofia LXXXIV, no. 1-2 (2016): 130.

MacIntyre, Alasdair. "Moral Philosophy and Contemporary Social Practice: What Holds Them Apart?" In The Tasks of Philosophy. Selected Essays, vol. 1, 117. Cambridge: Cambridge University Press, 2006.

Murray, Charles. Coming Apart: The State of White America, 1960-2010. New York, NY: Crown Forum, 2012.

Naughton, Michael and David Specht. Leading Wisely in Difficult Times: Three Cases on Faith and Work (co-author David Specht). Mahwah: Paulist Press, 2011.

Pieper, Josef. Leisure the Basis of Culture. South Bend, IN: St. Augustine's Press, 1998.

Rahner, Karl. "Theological Remarks on the Problem of Leisure." In Theological Investigations, vol. IV, 379, trans. Kevin Smyth. Baltimore: Helicon Press, 1966.

Ratzinger, Joseph. Introduction to Christianity, trans. J. R. Foster, 266. San Francisco: Ignatius Press, 1990.

Schindler, David. "Christology and the Imago Dei: Interpreting Gaudium et spes." Communio 23 (Spring 1996): 159.

Sheen, Fulton. Justice and Charity, 3. Charlotte: TAN Books, 2016.

Turkson, Cardinal Peter. "Protect the Earth, Dignify Humanity: The Moral Dimensions of Climate Change and Sustainable Development," delivered at Vatican City, April 28, 2015. http://www.casinapioiv.va/content/dam/ accademia/pdf/turkson.pdf. Accessed August 21, 2018.

Vatican's Pontifical Council for Justice and Peace. Vocation of the Business Leader. Vatican City: Pontifical Council for Justice and Peace, 2014. https:// www.stthomas.edu/media/catholicstudies/center/ryan/publications/ publicationpdfs/vocationofthebusinessleaderpdf/PontificalCouncil_4.pdf. 
Open Access This chapter is licensed under the terms of the Creative Commons Attribution 4.0 International License (http://creativecommons.org/licenses/ by $/ 4.0 /$ ), which permits use, sharing, adaptation, distribution and reproduction in any medium or format, as long as you give appropriate credit to the original author(s) and the source, provide a link to the Creative Commons license and indicate if changes were made.

The images or other third party material in this chapter are included in the chapter's Creative Commons license, unless indicated otherwise in a credit line to the material. If material is not included in the chapter's Creative Commons license and your intended use is not permitted by statutory regulation or exceeds the permitted use, you will need to obtain permission directly from the copyright holder.

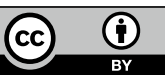

